\author{
О. В. Ільїна \\ доиент кафедри кримінального права та кримінологї \\ Київського національного університету ілені Тараса Шевченка
}

\title{
РІШЕННЯ СВРОПЕЙСЬКОГО СУДУ З ПРАВ ЛЮДИНИ ЯК ДЖЕРЕЛА КРИМІНАЛЬНОГО ПРАВА УКРАЇНИ
}

11 вересня 1997 р. Україна приєдналась до Конвенції про захист прав людини та основоположних свобод (далі - ЄКПЛ, Європейська конвенція). Із цього моменту громадяни України отримали право на звернення зі скаргами про порушення своїх прав та основоположних свобод про Європейського суду з прав людини (далі - ЄСПЛ).

Згідно з останніми показниками Україна займає провідне місце за кількістю поданих скарг до ЄСПЛ [1]. Звісно, це невтішна статистика, яка свідчить про неефективність національного механізму захисту прав та свобод громадян, який потребує удосконалення. Даний аспект набуває особливого значення в контексті європейської інтеграції України. Названий механізм передбачає приведення українського законодавства у відповідність до норм Європейської конвенції, засвоєння європейського досвіду, виконання рішень ЄСПЛ та врахування їх в подальшій правозастосовній діяльності. Фактично ідеться про використання рішень ЄСПЛ як джерел права. Проблема використання рішень ЄСПЛ як джерел права в національній системі права має двосторонній характер. Якщо на теоретичному рівні досі ведуться дискусії з приводу використання рішень ЄСПЛ як джерел національного права, то правозастосовна практика свідчить про активне їх використання. Так, в Єдиному реєстрі судових рішень міститься безліч посилань на рішення ЄСПЛ, судовою владою здійснюється упорядкування рішень ЄСПЛ з метою створення вільного доступу [2], здійснюється узагальнення практики ЄСПЛ для подальшого використання [3]. Повертаючись до теоретичних розробок у цій сфері, варто звернути увагу на те, що серед дослідників відсутня єдина позиція не тільки щодо приналежності рішень ЄСПЛ до джерел кримінального права, а й взагалі щодо того, що саме слід вважати джерелом права, яка ієрархічна структура джерел права. На сьогодні питання про систему джерел права і їх дослідження є одним 3 найбільш дискусійних та цікавих 3 погляду поглибленого дослідження. 3 огляду на це більшої актуальності набуває вивчення рішень ЄСПЛ як джерел кримінального права.

Дослідженням теоретичних аспектів віднесення рішень ЄСПЛ до джерел кримінального права займалися як вітчизняні, так і зарубіжні вчені. Серед них можна назвати П.П. Андрушко,
О.О. Дудорова, К.П. Задоя, Ю.М. Колосова, В.М. Кудрявцева, В.Т. Маляренко, В.П. Панова, П.М. Рабіновича, А.Н. Трайніна, І.В. Фісенка, M.I. Хавронюк та інших.

Метою статті є вивчення рішень ЄСПЛ як джерел кримінального права України.

Ратифікувавши Європейську конвенцію, Україна прийняла на себе зобов'язання з її виконання та впровадження у національну систему права. Водночас впровадження норм Конвенції передбачає не тільки запровадження її принципів, ідей у внутрішню систему, але і впровадження рішень ЄСПЛ, які прийняті у зв'язку із порушенням державою-учасницею норм Конвенції. Ідеться про нерозривний зв'язок Конвенції та рішень ЄСПЛ. Конвенція визначає діяльність Європейського суду як субсидіарний механізм захисту прав і свобод людини, при цьому основна відповідальність за їх гарантування покладається на національні правові системи. У ст. 1 Конвенції зафіксовано, що саме держави-учасниці беруть на себе обов'язок щодо забезпечення кожному, хто перебуває під їхньою юрисдикцією, прав і свобод, передбачених Конвенцією [4].

Як визначають автори, «дедалі більшого значення набуває практика ЄСПЛ, підвищується роль права ЄС у сфері боротьби зі злочинністю, формується загальноєвропейське кримінальне право, міцніє міжнародне співробітництво у боротьбі із загальними загрозами кримінального характеру» [5, с. 35$]$.

Відносно рішень ЄСПЛ у науковому просторі відсутня єдність поглядів. Так, Н. Блажівська на підставі проведеного дослідження доходить такого висновку: «У романо-германській правовій системі мотивувальні позиції Європейського суду повинні займати місце поруч із законом, в англосаксонській - поруч із прецедентом найвищої сили, а там, де доктрина виступає основним джерелом права, - прирівнюватися до доктрини. Якщо національні правові системи піддаються інтернаціоналізації, рішення Європейського Суду повинні висуватися на перший план». Водночас авторка зазначає: «У сучасних умовах передчасно оголошувати рішення Європейського суду частиною національного права. Правильніше застосовувати формулу "входять у правову систему» $[6$, c. 228]. 
Інші вчені визначають, що «джерелами кримінального права можна вважати такі правові позиції ЄСПЛ, викладені у його рішеннях, у яких дається тлумачення норм Конвенції <...>» [7, с. 58]. Позитивно оцінюючи цитовану тезу в цілому, слід вказати, що фактично діяльність ЄСПЛ спрямована саме на тлумачення Конвенції, тому знайти рішення ЄСПЛ, яке не містить у собі тлумачення Конвенції або посилання на інше рішення ЄСПЛ із тлумаченням Конвенції, не видається можливим.

$\mathrm{y}$ наукових джерелах містяться позиції, що практику ЄСПЛ слід розглядати як потенційне джерело кримінального права України. Визнання практики Європейського суду джерелом права $\epsilon$ невідворотним процесом адаптації національного законодавства України до законодавства Європейського Союзу [7, с. 59]. Погоджуючись у цілому із наведеною позицією, слід вказати, що, на нашу думку, практика ЄСПЛ - не потенційне джерело кримінального права, а реальне джерело права, адже адаптація українського законодавства до європейського вже частково відбулася. Окрім того, необхідною також є уніфікація (або гармонізація) кримінального законодавства європейських держав, до яких належить і Україна.

Гармонізація загальноєвропейського кримінального законодавства, тобто приведення його у відповідність до європейських стандартів на підставі положень створеного у межах Ради Європи та Європейського Союзу кримінального законодавства, є об'єктивно необхідною для підвищення ефективності боротьби з міжнародними злочинами та злочинами міжнародного характеру на євразійському континенті [8, с. 57].

Здійснюючи проміжний висновок, хотілось би вказати, що, на наш погляд, рішення ЄСПЛ вже давно стали частиною національної системи права, в тому числі і такої галузі, як кримінальне право. Для підтвердження цієї тези слід звернутися до Закону України «Про виконання рішень та застосування практики Європейського суду з прав людини» № 3477-IV . Здавалося б, прийняття цього закону і сама його назва мали б зупинити дискусії 3 приводу використання практики ЄСПЛ як джерела права. Однак із прийняттям даного Закону наукові дискусії не згасають. Вивчаючи зміст Закону № 3477-IV, слід звернути увагу на ст. 17, в якій сказано: «Суди застосовують при розгляді справ Конвенцію та практику Суду як джерело права». Фактично законодавець закріпив як джерело права не тільки Конвенцію, а й практику ЄСПЛ [9]. Вважаємо, що дане положення є цілком логічним 3 огляду на те, що Конвенція та діяльність суду нерозривно пов'язані між собою. Оскільки Україна приєдналася до ЄКПЛ, практика ЄСПЛ автоматично стала невід'ємним джерелом права України.

Що стосується Конвенції, то вона має такий же статус, як і інші законодавчі акти, тобто є части- ною національного законодавства України згідно із положенням ст. 9 Конституції України, яка проголошує: «Чинні міжнародні договори, згода на обов'язковість яких надана Верховною Радою України, є частиною національного законодавства України. Укладення міжнародних договорів, які суперечать Конституції України, можливе лише після внесення відповідних змін до Конституції України».

Окрім того, у ч. 1 ст. 3 Кримінального кодексу України встановлено, що цей Кодекс грунтується на Конституції України та загальновизнаних принципах і нормах міжнародного права. Як визначають науковці, даний нормативний орієнтир викликає зацікавлення, а згадана нормативна вказівка на загальновизнані принципи та норми міжнародного права є сумнівною з огляду на невизначеність їх статусу в національній правовій системі України [10, с. 105].

Якщо на питання «Чи є практика ЄСПЛ джерелом права в Україні?» ЗУ № 3477-IV дає однозначну відповідь, то на питання «Чи належать до джерел права України рішення ЄСПЛ, які прийняті відносно інших країн?» названий Закон не дає відповіді. У ст. 46 ЄКПЛ визначено, що держави-учасниці зобов'язані виконувати остаточні рішення Суду в будь-яких справах, у яких вони є сторонами. Тобто цитована норма вказує на те, що джерелом права в Україні є лише ті рішення Суду, які винесені за результатами розгляду справ щодо України. Але сучасні реалії свідчать про протилежне. Деякі науковці мають думку, що держави-учасниці Конвенції повинні враховувати не лише національні рішення, але й рішення, винесені стосовно третіх країн. Автори зазначають: «Держави, які не були сторонами в конкретній справі, повинні виносити більше уроків із таких постанов, оскільки вказані постанови можуть навчити їх того, як уникнути подібних порушень в майбутньому і відповідним чином змінити власну правову систему і правозастосовну практику. Якби держави-учасниці добре знали стандарти, які випливають із рішень Європейського суду відносно інших країн і належним чином здійснювали би зміни у своїх правових системах чи правозастосовній практиці, це скорочувало б і кількість скарг, які можуть подаватися до Європейського суду» $[11$, с. 38$]$.

Звужуючи радіус дослідження до галузі кримінального права, слід звернутися до галузевих законодавчих актів, зокрема й до Кримінального кодексу України. Аналіз названого документа свідчить про те, що в ньому відсутні вказівки на використання практики ЄСПЛ [12]. На противагу Кримінальному кодексу України Кримінальний процесуальний кодекс України в ч. 5 ст. 9 закріпив: «Кримінальне процесуальне законодавство України застосовується з урахуванням практики Євро- 
пейського суду з прав людини» [13]. Законодавець закріпив практику ЄСПЛ як джерело кримінального процесуального права України. Як джерело права була закріплена не тільки практика щодо України, а загалом вся практика ЄСПЛ. 3 метою подолання законодавчої прогалини пропонуємо закріпити аналогічну норму у Кримінальному кодексі України. Вказаний законодавчий крок відобразить сучасні підходи до визначення джерел кримінального права та дозволить завершити наукові дискусії із цього приводу, тому що наразі деюре в галузі кримінального права обов'язковими $е$ лише рішення, прийняті ЄСПЛ відносно України, а де-факто держави-учасниці мають використовувати практику ЄСПЛ щодо будь-якої держави задля виконання Конвенції, яку тлумачить Європейський суд у своїх рішеннях.

У контексті досліджуваної теми цікавою видається позиція щодо того, що в тих державах, в яких судові органи у певному розумінні функціонують незалежно від виконавчої та законодавчої влади, дія рішень Європейського суду визначається судовою владою [14]. Правові позиції ЄСПЛ займають особливе місце серед джерел, якими керуються національні суди та інші органи державної влади у своїй діяльності. Вони є результатом тлумачення норм Конвенції, а також вираженням ставлення ЄСПЛ до певної правової проблеми $[15$, c. 30]. Підтримуючи цитовані наукові позиції, хотілось би додати, що для того, щоб відповісти на питання «Чи є практика ЄСПЛ джерелом кримінального права України?», необхідно дослідити правозастосовну практику національних судів, адже саме вона має проілюструвати те, чи використовується практика ЄСПЛ як джерело права.

Так, у вироку Димитровського міського суду Донецької області у справі № 226/1/19 від 08 липня 2019 р. суд зазначив: «Згідно з практикою Європейського суду з прав людини, яка є джерелом права в Україні, порушення прав людини тягне моральні страждання та виникнення моральної шкоди, а тому факт страждань доведення не потребує. Для суду достатньою підставою присудження компенсації моральної шкоди є сам факт порушення права (рішення $Є \mathrm{C}$ від 15 жовтня 2009 р. у справі «Антипенко проти Російської Федерації»). Оскільки винуватість обвинувачених у інкримінованому їм злочині є доведеною, суд з врахуванням доводів потерпілого, глибини і тривалості душевних страждань, яких він зазнав від вчиненого правопорушення, та встановлених обставин вважає за необхідне стягнути з них солідарно на користь потерпілого моральне відшкодування в розмірі 5000 грн, у такий спосіб частково задовольнивши вимоги потерпілого щодо стягнення морального відшкодування, що відповідатиме принципам розумності, виваженості і справедливості. У задоволенні іншої частини позовних вимог відмовлено» [16].
Гусятинський районний суд Тернопільської області у справі № 596/982/19 у вироку від 5 липня 2019 р. також посилається на практику ЄСПЛ як джерело права та зазначає: «Згідно зі ст. 17 Закону України «Про виконання рішень та застосування практики Європейського суду з прав людини» від 23.02.2006 р. при розгляді справ суди застосовують Конвенцію про захист прав людини та основоположних свобод 1950 р. та практику Європейського суду з прав людини як джерело права. Відповідно до п. 43 рішення Європейського суду з прав людини від 14 лютого 2008 р. у справі «Кобець проти України» доведення має випливати із сукупності ознак чи неспростовних презумпцій, достатньо вагомих, чітких і узгоджених між собою, а за відсутності таких ознак не можна констатувати, що винуватість обвинуваченого доведена поза розумним сумнівом. Розумним $€$ сумнів, який грунтується на певних обставинах та допустимих відомостях, визнаних доказами, або відсутності таких відомостей. Цей сумнів є таким, який змусив би особу втриматися від прийняття рішення у питаннях, що мають для неї найбільш важливе значення. Згідно з практикою Європейського суду з прав людини критерієм доведення винуватості особи у вчиненні інкримінованого їй кримінального правопорушення $\epsilon$ те, що саме прокурор має довести вину обвинуваченого поза межами розумного сумніву. Ухвалюючи обвинувальний вирок, суд має бути переконаний поза межами розумного сумніву, що кожен із суттевих елементів інкримінованого особі кримінального правопорушення, є доведеним (справа «Дж. Мюрей проти Сполученого Королівства»)»[17].

На підтвердження того, що судова влада застосовує не тільки практику ЄСПЛ, прийняту відносно України, але і практику ЄСПЛ щодо інших країн-учасниць Європейської конвенції, можна привести рішення Красилівського районного суду Хмельницької області, який у вироку у справі № 677/483/19 від 4 липня 2019 р. зазначає, що 17.07.1997 р. Україна ратифікувала Європейську Конвенцію про захист прав людини і основоположних свобод, а також Протоколи $1,2,4,7,11$, які є невід'ємною частиною Конвенції, чим визнала її дію в національній правовій системі, а також обов'язковість рішень Європейського суду з прав людини з усіх питань, що стосуються тлумачення і застосування Конвенції. Згідно зі статтею 1 Протоколу № 1 до Конвенції про захист прав людини і основоположних свобод кожна фізична чи юридична особа має право на повагу до своєї власності. Особа може бути позбавлена свого майна не інакше як в інтересах суспільства та на умовах, передбачених законом і загальними принципами міжнародного права. Перша і найбільш важлива вимога зазначеної правової норми полягає в тому, що будь-яке втручання публічної влади в право 
на повагу до власності має бути законним. Також передбачається, що держава уповноважена здійснювати контроль за використанням власності шляхом забезпечення виконання законів. Як у справі «Бакланов проти Росії» (рішення від 09.06.2005 р.), так і в справі «Фрізен проти Росії» (рішення від 24.03.2005 р.) Суд зазначив, що досягнення справедливого балансу між загальними інтересами суспільства та вимогами захисту основоположних прав особи лише тоді стає значимим, якщо встановлено, що під час відповідного втручання був дотриманий принцип законності, тому воно не було свавільним. Крім того, у справі «Ізмайлов проти Росії» (п. 38 рішення від 16.10.2008 р.) Суд встановив, що, щоб втручання вважалося пропорційним, воно має відповідати тяжкості правопорушення і не становити особистий і надмірний тягар для особи [18].

Київський районний суд м. Одеси у справі № 520/5755/18 від 8 липня 2019 р. доходить висновку, що «відповідно до сформованої позиції Європейського суду з прав людини наявність державного інтересу не можна використовувати як обгрунтування для використання доказів, отриманих в результаті поліцейської провокації, оскільки застосування таких доказів наражає обвинуваченого на ризик остаточно позбавитись справедливого судового розгляду із самого початку, а внутрішньодержавне законодавство не має дозволяти використання доказів, отриманих в результаті підбурювання з боку державних агентів, інакше таке законодавство не відповідатиме принципу справедливого судочинства (Рішення ЄСПЛ у справах «Тейксейра де Кастро проти Португалії» від 9 червня 1998 р., «Худобін проти РосійськоїФедерації» від 26 жовтня 2006 р., «Ваньян проти Російської Федерації» від 15 грудня 2005 р., «Раманаускас проти Литви» від 5 лютого 2008 р.)» [19].

Якщо брати за основу тезу, що дія рішень Свропейського суду визначається судовою владою країни, наведені судові рішення наочно демонструють, що рішення ЄСПЛ є джерелом кримінального права України. При цьому цей висновок стосується рішень ЄСПЛ, які прийняті як відносно України, так і відносно інших країн-учасниць Свропейської конвенції.

\section{Jimepamypa}

1. Центр інформації про права людини. URL: https://humanrights.org.ua/material/ukrajina vzhe ne_lider_za_kilkistjiu_skarg_proti_neji_u_jespl_ aktualna statistika vid jevrosudu ta minjiustu (дата звернення: 11.07.2019).

2. Захист інтересів держави в Свропейському суді. URL: https://minjust.gov.ua/cat_9329 (дата звернення: 11.07.2019).

3. Фулей T.І. Застосування практики Європейського суду з прав людини при здійсненні правосуддя : науково-методичний посібник для суддів. 2-ге вид. випр., допов. Київ, 2015. 208 с.
4. Конвенція про захист прав людини і основоположних свобод : міжнародний документ від 04.11.1950 p. URL: http://zakon2.rada.gov.ua/ laws/show/995_004 (дата звернення: 11.07.2019).

5. Актуальні проблеми кримінального права : навч. посіб. / В.М. Попович, П.А. Трачук, А.В. Андрушко, С.В. Логін. Київ : Юрінком Інтер, 2009. 256 с.

6. Блажівська Н. До питання про місце рішень Європейського суду з прав людини у національній правовій системі. Підприємниитво, господарство і право. 2018. № 4. C. 226-230, С. 228.

7. Соболь O.I., Южека Р.С., Рішення Свропейського суду з прав людини як джерела кримінального права України. Науковий вісник Херсонського державного університету. 2018. Вип. 2. Том 2. С. 57-59.

8. Дудоров 0.O., Хавронюк М.I. Кримінальне право : навчальний посібник / за заг. ред. М.І. Хавронюка. Київ : Ваіте, 2014. 944 с.

9. Про виконання рішень та застосування практики Європейського суду з прав людини : Закон України від 23.02.2006 р. № 3477-IV. Урядовий кур’єр. 30.03.2006. № 60 .

10. Задоя К.П. Положення частини першої статті 3 Кримінального Кодексу України як приклад невдалого «трансплантанту». Вісник Вищої ради юстииї̈. 2012. № 3 (11). C. 105-113.

11. Беляневич О.А. Про застосування практики Європейського суду з прав людини. Вісник КНУ ім. Тараса Шевченка. Серія «Юридичні науки». 2009. № 81 . C. $32-38$.

12. Кримінальний кодекс України : Закон України від 05.04.2001 р. № 2341-III. Відолості Верховної Ради України (ВВР). 2001. № 25-26. Ст. 131.

13. Кримінальний процесуальний кодекс України : Закон України від 13.04.2012 р. № 4651-VI. Відомості Верховної Ради України (ВВР). 2013. № 9-10, № 11-12, № 13. Ст. 88 .

14. Laurence R. Helfer. Redesigning the European Court of Human Rights: Embeddedness as a Deep Structural Principle of the European Human Rights Regime. The European Journal of International Law. Vol. 19. No. 1. URL: https://scholarship.law.duke.edu/cgi/ viewcontent .cgi? article $=2591 \&$ context $=$ faculty scholarship (дата звернення: 11.07.2019).

15. Завгородній В.А. Рішення Свропейського Суду з прав людини як акти тлумачення норм конвенції про захист прав людини та основоположних свобод. Науковий вісник Ужгородського нащіонального університе ту. Серія «Право» / редкол. Ю.М. Бисага, Д.М. Белов, С.Б. Булеца та ін. Ужгород : Видавничий дім «Гельветика», 2014. Вип. 24. Т. 1. С. 29-33.

16. Вирок Димитровського міського суду Донецької області від 08 липня 2019 р., судова справа № 226/1/19. URL: https://opendatabot.ua/court/82870635-df97fc96c 428cb869f01dcda617e46db (дата звернення: 11.07.2019).

17. Вирок Гусятинського районного суду Тернопільської області від 5 липня 2019 р., судова справа № 596/982/19. URL: https://opendatabot.ua/ court/82840909-3038cc03dc2eb222a4deee06f72d7090 (дата звернення: 11.07.2019).

18. Вирок Красилівського районного суду Хмельницької області від 4 липня 2019 р., судова справа № 677/483/19. URL: https://opendatabot.ua/court/ 82843312-22665288372e5ce9783fe9faeda2b028 (дата звернення: 11.07.2019).

19. Вирок Київського районного суду м. Одеси від 8 липня 2019 р., судова справа № 520/5755/18. URL: https://opendatabot.ua/court/82861124-43262 45167980e0a24aa97a05f90a2f0 (дата звернення: 11.07.2019) 


\section{Анотація}

Ільӥна О. В. Рішення Європейського суду з прав людини як джерела кримінального права України. Стаття.

У статті розглянуто рішення Свропейського суду з прав людини як джерела кримінального права України. Окрему увагу приділено розгляду наукових поглядів щодо віднесення практики Європейського суду з прав людини до джерела права України. Констатовано відсутність єдиного погляду науковців на означене питання. Також досліджено законодавчі норми з приводу закріплення практики Європейського суду 3 прав людини як джерела національного права. Визначено, що Закон України «Про виконання рішень та застосування практики Європейського суду з прав людини» № 3477- IV закріпив практику Суду як джерело права. Водночас названий Закон не визначив того, чи обов'язкова для України практика Суду щодо інших держав-учасниць Конвенції про захист прав людини та основоположних свобод. Фактично згадана законодавча норма закріпила те, що джерелом права в Україні $\epsilon$ лише ті рішення Суду, які винесені за результатами розгляду справ щодо України. Проте наразі дедалі актуальнішою стає позиція, що держави-учасниці Конвенції про захист прав людини і основоположних свобод мають враховувати не лише національні рішення, але й рішення, винесені відносно третіх країн, щоб уникнути подібних порушень в майбутньому і відповідним чином змінити власну правову систему і правозастосовну практику.

У статті запропоновано закріпити у Кримінальному кодексі України норму про те, що кримінальне законодавство України застосовується з урахуванням практики Європейського суду з прав людини. Вказаний законодавчий крок відобразить сучасні підходи до визначення джерел кримінального права та дозволить завершити дискусії з приводу віднесення рішень Європейського суду з прав людини до джерел кримінального права України.

Окрему увагу приділено вивченню правозастосовної практики українських судів 3 метою проілюструвати активне використання практики Європейського суду з прав людини як джерела кримінального права України. Продемонстровано те, що дія рішень Європейського суду з прав людини визначається судовою владою.

Подальше дослідження надало змогу дійти висновку, що джерелом права України, зокрема й галузі кримінального права України, є практика Європейського суду з прав людини відносно будь-якої держави-учасниці Конвенції про захист прав людини та основоположних свобод.

Ключові слова: джерело права, кримінальне право, Європейський суд 3 прав людини, Конвенція про захист прав людини та основоположних свобод, захист прав людини, система права, національне право.

\section{Summary}

Ilina O. V. Judgments of the European Court of Human Rights as a source of criminal law of Ukraine. $-\mathrm{Ar}$ ticle.

The research paper deals with the decision of the European Court of Human Rights as a source of criminal law in Ukraine. Particular attention is paid to the consideration of scientific points of view on attributing the case-law of the European Court of Human Rights to sources of law in Ukraine. The absence of a unified point of view of scholars on this issue was stated. Legislative provisions regarding enshrinement of the case-law of the European Court of Human Rights as a source of national law were studied. It is determined that the Law of Ukraine "On the Enforcement of Judgments and the Application of the Case-Law of the European Court of Human Rights" No. 3477- IV establishes the case-law of the Court as a source of law. At the same time, the aforementioned law did not determine whether the Court's case-law on other States parties to the Convention for the Protection of Human Rights and Fundamental Freedoms was binding on Ukraine. In fact, the mentioned legislative provision stipulates that the source of the law in Ukraine is only those judgments of the Court which were passed as a result of the consideration of cases against Ukraine. But it is now increasingly relevant that States Parties to the Convention for the Protection of $\mathrm{Hu}$ man Rights and Fundamental Freedoms should take into account not only "national" judgments, but also judgments passed against third countries in order to avoid such violations in the future and change their own legal system and law enforcement practices in a proper manner.

The research paper proposes to enshrine the provision in the Criminal Code of Ukraine that the criminal legislation of Ukraine is applied taking into account the case-law of the European Court of Human Rights. This legislative step will reflect current approaches to identifying sources of criminal law and will allow the completion of discussions regarding the classification of judgments of the European Court of Human Rights as sources of criminal law of Ukraine.

Particular attention was paid to the study of the law enforcement practice of the Ukrainian courts in order to illustrate the active use of the case-law of the European Court of Human Rights as a source of criminal law in Ukraine. In fact, it was demonstrated that the effects of judgments of the European Court of Human Rights are determined by the judicial authority.

Further research led to the conclusion that the source of Ukrainian law, and, in particular, the criminal law of Ukraine, is the practice of the European Court of Human Rights against any State party to the Convention for the Protection of Human Rights and Fundamental Freedoms.

Key words: source of law, criminal law, European Court of Human Rights, Convention for the Protection of Human Rights and Fundamental Freedoms, protection of human rights, system of law, national law. 